\title{
Inbreeding, Coancestry, and Founding Clones of Almonds of California, Mediterranean Shores, and Russia
}

\author{
Ali Lansari \\ Ecole Nationale d'Agriculture, B.P. S/40, Meknes, Morocco \\ Dale E. Kester \\ Department of Pomology, University of California, Davis, CA 95616 \\ Amy F. Iezzoni \\ Department of Horticulture, Michigan State University, East Lansing, MI 48824
}

Additional index words. Prunus dulcis, germplasm

\begin{abstract}
The mean inbreeding and coancestry coefficients were calculated for almond, Prunus dulcis (Miller) D.A. Webb, cultivars from the United States, France, Spain, Israel, and Russia. To improve cultivars to meet market demand, the recurrent use of four selections as parents in U.S. breeding programs has resulted in a mean inbreeding coefficient (F) of 0.022 in this collection. In France, a single cultivar, Ferralise, has an inbreeding value of $F=0.250$, while cultivars of other almond-producing countries are noninbred $(F=0)$. Due to the use of common parents, U.S., Russian, and Israeli cultivars share coancestry, while coancestries also exist between French and Spanish almond germplasm. Cultivars of known parentage in the United States, Russia, Israel, France, and Spain trace back, respectively, to nine, eight, three, four, and three founding clones. Future almond-breeding programs may narrow the genetic base and thereby limit genetic gain.
\end{abstract}

Genetic diversity of crop plants decreases the likelihood of epidemic crop losses to insects, diseases, and unfavorable stress conditions. Maximizing genetic diversity is also important in breeding programs, since it enhances the potential gain from selection. Yet Prunus cultivars grown in the United States have a very narrow genetic base. Sour cherry (P. cerasus L.) production in the United States is a monoculture of one cultivar, and most commercial peach [P. persica (L.) Batsch.] cultivars trace back to six parental cultivars (Scorza et al., 1985). In almond (P. dulcis synonymous $P$. amygdalus Batsch) breeding programs, the extensive use of a few cultivars as parents suggests that the almond germplasm base may also be similarly narrow (Kester et al., 1991).

The cultivated almond is believed to have originated from the wild species Amygdalus communis L. (Evreinoff, 1958; Grasselly and Crossa-Raynaud, 1980; Kester, 1990; Kester et al., 1991; Kester and Asay, 1975). A. communis is thought to be derived from hybridization among several wild species of the subgenus Amygdalus such as P. fenzliana, P. bucharica (Grasselly and Crossa-Raynaud, 1980; Kester and Asay, 1975), P. ulmifolia (Evreinoff, 1958; Kester and Asay, 1975), and possibly P. kuramica (Grasselly and Crossa-Raynaud, 1980; Kester et al., 1991), and $P$. kotschii (C. Grasselly, personal communication). Native habitats of the cultivated almond are between 700 and $1700 \mathrm{~m}$ on the Kapet Dagh Mountains between Iran and Russia and on the Tian Sian Mountains between western Mongolia and Russia (Grasselly, 1976; Grasselly and Crossa-Raynaud, 1980; Kester, 1990; Kester and Asay, 1975). Almond cultivation began during the 3rd millennium B.C. (Socias i Company, 1990) with sweet kerneled selections that arose by mutation in wild populations of normally bitter

Received for publication 28 Nov. 1993. Accepted for publication 10 Mar. 1993. Accepted for publication 10 Mar. 1994. The authors wish to thank Ch. Grasselly, R. Socias i Company, and J. Luby for their critical reading of the manuscript. This research was supported in part by the U.S. Agency for International Development (U.S.-AID) Agronomic Institute Project no. 608-0160. The cost of publishing this paper was defrayed in part by the payment of page charges. Under postal regulations, this paper therefore must be hereby marked advertisement solely to indicate this fact. seedlings (Grasselly, 1976; Kester, 1990). Cultivated almonds were introduced to Greece before 350 B.C. (Kester, 1990; Socias i Company, 1990) and spread around the Mediterranean through commercial routes (Grasselly and Crossa-Raynaud, 1980; Kester, 1990; Kester et al., 1991; Kester and Asay, 1975; Socias i Company, 1990). The Arabs introduced almonds into North Africa and the Iberian peninsula during the 6 th and 7 th century A.D. (Kester, 1990). The introduction of almonds into America, Australia, and South Africa occurred between 1850 and 1900 (Kester, 1990). Currently almond culture is concentrated in three world regions: Asia, the shores of the Mediterranean Sea, and California. Limited production occurs in Australia, South Africa, Argentina, and Chile (Kester et al., 1991).

Since antiquity, the cultivated almond has been propagated both by seeds and as clones and, therefore, may have undergone more selection pressure than a predominantly clonally propagated species. As a result of this selection pressure, the domesticated species progressively differentiated into separate geographical ecotypes in differing environments (Grasselly, 1976; Grasselly and Crossa-Raynaud, 1980; Kester, 1990). Cultivars were selected from seedling almond populations, grafted to propagate desirable clones, and later established in commercial orchards (Kester, 1990; Kester et al., 1991; Kester and Asay, 1975; Socias i Company, 1990). Most of the leading cultivars originated from chance seedlings selected from local gene pools (Kester et al., 1991).

Almond production and cultivar development has followed different patterns in different parts of the world: 1) Seedlings and a few locally selected and vegetatively propagated cultivars are grown commercially in Afghanistan, Bulgaria, India, Iraq, Iran, Morocco, Pakistan, Romania, Syria, Turkey, and the former Yugoslavia. 2) Breeding and evaluation programs exist in Australia, Greece, Israel, Italy, Spain, Tunisia, and the United States, but most of their major cultivars originated from chance seedlings from local ecotypes. 3) In France and Russia, the almond industries rely primarily on cultivars released from breeding programs, while old seedling or clonally selected cultivars from landraces now exist only in germplasm collections. Almond is an obligate outcrosser 
and susceptible to inbreeding depression characterized by low vigor and reduced flower number, fruit set, seed germination, seedling survival, leaf abnormalities, and disease resistance (Grasselly and Olivier, 1976, 1981; Grasselly et al., 1981; Socias i Company, 1990). When the 'Tuono' cultivar from the Puglia region of Italy was crossed with unrelated cultivars, no inbreeding depression was reported. However, when 'Tuono' was crossed with other cultivars from the same region and self-pollinated, inbreeding depression was observed as low vigor and a longer juvenile period (Socias i Company, 1990). In breeding programs, when self-pollination or sib-mating is practiced, the level of inbreeding in the progeny increases. The objective of self-pollinations or related crosses is generally to maintain the uniformity in kernel traits required by the industry. As a result, there is fixation at desirable loci with an associated reduction of fitness due to a loss of heterozygosity. The extensive use of related parents in almond breeding programs raises a concern of possible inbreeding depression. The objective of the present study was to compare the level of inbreeding, coancestry, and the genetic contribution of founding clones among almond germplasm in selected almond-producing countries.

\section{Materials and Methods}

Pedigrees of almond cultivars were collected from breeding records and published sources (Anonymous, 1977; Asai et al., 1994; Barbera et al., 1984; Bastide and Souty, 1976; Brooks and Olmo, 1972, 1982; Chessa and Pala, 1985; Costetchi, 1967; Egea et al., 1984; Fanelli, 1939; Felipe, 1976, 1984; Felipe and Socias i Company, 1985, 1987; Georgio et al., 1985; Grasselly and Crossa-Raynaud, 1980; Jaouani, 1976; Kester et al., 1984, 1991; Monastra et al., 1984; Serafimov, 1976; Spiegel-Roy, 1976; SpiegelRoy and Kochba, 1976a, 1976b; Spiegel-Roy et al., 1982; Stylianides, 1976, 1977; Vargas Garcia, 1975; Vlasic, 1976; Wood, 1924). Parental relationships for many cultivars of unknown origin have been determined by isozyme techniques (Hauagge et al., 1987), or through pollen incompatibility studies (Asai et al., 1994; Crossa-Raynaud and Grasselly, 1985; Godini et al., 1977). Pedigrees for 123 almond cultivars were obtained, of which 85 were American, 12 Russian, 6 Israeli, 12 French, 5 Spanish, and 3 Italian (Table 1). 'Princesse' used in the United States and Russian breeding programs was considered the same in our analysis since both the Russian and U.S. 'Princesse' trace back to the same French papershell germplasm. However, the U.S. and Russian 'Princesse' may represent different clonal selections (Ch. Grasselly, personal communication).

The inbreeding coefficient $(\mathrm{F})$, given by the following formula, is defined as the probability that two genes at any locus in an individual are replicates of one and the same gene in a previous generation. These genes are said to be "identical by descent" (Wright, 1922).

$$
F_{x}=\Sigma\left[\left(\frac{1}{2}\right)^{n_{1}+n_{2}+1}\left(1+F_{A}\right)\right]
$$

where $\mathrm{n}_{1}=$ number of generations from one parent back to the common ancestor, $\mathrm{n}_{2}=$ number of generations from the other parent back to the common ancestor, and $\mathrm{F}_{\mathrm{A}}=$ inbreeding coefficient of the common ancestor.

Estimation of the level of inbreeding by calculation of the inbreeding coefficient gives a reasonable approximation of the probability of gene fixation, even when the initial gene frequencies are not known (Wright, 1922). Considering that almond is an obligate outcrosser because it is self-incompatible, all parents of unknown origin were assumed non-inbred and unrelated. The seed
Table 1. Almond cultivars from the U.S., Russia, France, Israel, Spain, and Italy.

\begin{tabular}{|c|c|c|}
\hline \multicolumn{3}{|c|}{ United States } \\
\hline Arbuckle & I.X.L. & Profuse \\
\hline Bigelow & Janice & Reinero \\
\hline Bonita & Jeffries & Ripon \\
\hline Ballico & JordanoloRoy & Roy \\
\hline Bell & Jubilee & Ruby \\
\hline Burbank & Kapareil & Robson \\
\hline Butte & Kern Royal & Sans Faute \\
\hline Carmel & Kutsch & Sonora \\
\hline Craven & Livingston & Solano \\
\hline Carrion & La Marie & Sydney Special \\
\hline Cressey & La Prima & Smith X.L \\
\hline Davey & Leweling & Standard \\
\hline Drake & Legrand & Spencer \\
\hline Dehn & Merced & Sauret \#1 \\
\hline Emerald & Milow & Sauret \#2 \\
\hline Empire & Mission (Texas) & Swanson \\
\hline Elsie & Monterey & Tardy Nonpareil \\
\hline Eureka & Moneytree & Thompson \\
\hline Fritz & Monarch & Tioga \\
\hline Golden Street & Norman & Tokyo \\
\hline Godde & Nonpareil & Titan \\
\hline Granada & Ne Plus Ultra & Utah \\
\hline Grace & Northland & Valenta \\
\hline Heart & Pioneer & Vesta \\
\hline Hoover & Planada & Walton \\
\hline Hallshardy & Padre & Wawona \\
\hline Harpareil & Peerless & Yosemite \\
\hline Harriott & Paxman & \\
\hline Harvey & $\begin{array}{l}\text { Price Cluster } \\
\text { Russia }\end{array}$ & \\
\hline Bumagnoskorlupii & Nikitski 62 & Primorski \\
\hline Desertnyi & Nikitski 1 & Preanii \\
\hline Krimski & Nikitski 53 & Sovietski \\
\hline Miagkoskorlupii & $\begin{array}{c}\text { N.Pozdentvetusei } \\
\text { France }\end{array}$ & Yaltinski \\
\hline $\mathrm{Ai}$ & Ferragnes & Lauranne \\
\hline Ardechoise & Ferraduel & Princesse \\
\hline Belle d'Aurons & Ferrastar & Stelliette \\
\hline Ferralise & $\begin{array}{l}\text { Lanugedoc } \\
\text { Israel }\end{array}$ & Tardive de la Verdière \\
\hline Dagan & Poriah 10 & Samish \\
\hline Greek & $\begin{array}{l}\text { Solo } \\
\text { Spain }\end{array}$ & Kochba \\
\hline$A-10-6$ & Jordan & Marcona \\
\hline Ayles & $\begin{array}{l}\text { Moncayo } \\
\text { Italy }\end{array}$ & \\
\hline Cristomorto & Reams & Tuono \\
\hline
\end{tabular}

parent involved in an open-pollination was also assumed to be unrelated to the pollen parent. Inbreeding coefficients were calculated using a computer program of Hancock and Siefker (1982).

The coancestry coefficient (CC) of prospective progeny of two individuals is equal to one half the covariance of the parents. Since $\mathrm{F}$ of an individual is equal to the $\mathrm{CC}$ of its parents, the $\mathrm{CC}$ of two cultivars was calculated as $\mathrm{F}$ of their prospective progeny. Common CC are 0.500 for self-pollination, 0.250 for parent-offspring and full-sib matings, 0.125 for half-sib matings, and 0.063 for firstcousin matings. Parentage of a mutant of a cultivar is considered 
to be the same as parentage of the mutated cultivar. Thus only the $\mathrm{CC}$ value of the original cultivar is presented. However, the CC values of all the cultivars (Table 1), the mutants plus the original cultivar, were considered for mean calculations.

The genetic contribution (GC) of a founding clone to a cultivar was calculated as described by Sjulin and Dale (1987):

$$
G C=\sum_{1}^{x}\left(\frac{1}{2}\right)^{n}
$$

where $\mathrm{n}=$ number of generations in a pedigree pathway between the founding clone and the cultivar, and $\mathrm{x}=$ number of pathways between the founding clone and the cultivar.

\section{Results}

Inbreeding coefficients. Only 10 of the 123 almond cultivars analyzed had an inbreeding coefficient other than zero (Table 2). U.S. cultivars ranged from $F=0$ to 0.375 with 9 of the 85 cultivars having $\mathrm{F}>0$ (Table 2). The mean for the U.S. cultivars was $\mathrm{F}=$ 0.022. Except for the French cultivar 'Ferralise', with $F=0.250$, all the remaining almond cultivars in France, Russia, Spain, and Israel are noninbred $(\mathrm{F}=0)$.

Founding clones. The U.S. almond cultivars trace back to nine cultivars, with 'Nonpareil', 'Mission', and the French 'Princesse' and 'Languedoc' representing the highest genetic contribution (GC) (Table 3). 'Nonpareil', a seedling of 'Princesse', contributes $37.9 \%$ of the genetic composition of U.S. cultivars. This cultivar is related to $65 \%$ of the cultivars studied. 'Mission' (Syn. 'Texas') has a GC of $30.2 \%$ and a coancestry relationship with $49 \%$ of the cultivars under study.'Princesse' has a GC of $21.6 \%$, while 'Languedoc' has a GC of $14.1 \%$. The gene pool in California is dominated by descendants of 'Nonpareil' and 'Mission' (Hauagge et al., 1987; Kester et al., 1991). 'Nonpareil', 'Ne Plus Ultra', 'I.X.L.', and 'Mission' are considered founding clones because of their extensive use (mostly 'Mission' and 'Nonpareil') in breeding programs. In addition, they originated from the first generation of selected almonds. The maternal parent of 'Nonpareil' (as well as 'Ne Plus Ultra' and 'I.X.L.') is believed to be a variety known in

Table 2. Country of origin, parentage, and inbreeding coefficients for 10 almond cultivars.

\begin{tabular}{|c|c|c|c|}
\hline $\begin{array}{l}\text { Country } \\
\text { of origin }\end{array}$ & Cultivar & $\begin{array}{l}\text { Presumed or } \\
\text { reported parentage }\end{array}$ & $\begin{array}{l}\text { Inbreeding } \\
\text { coefficient } \\
\text { (F) }\end{array}$ \\
\hline U.S. & $\begin{array}{c}\text { Sonora } \\
(5 a-20)\end{array}$ & $\begin{array}{l}\text { 21-19W [Nonpareil x (Nonpareil x } \\
\text { Eureka) A1-30] x 22-20 [Nonpareil } \\
\text { x (Nonpareil x Eureka) A1-30] }\end{array}$ & 0.375 \\
\hline U.S. & $\begin{array}{l}\text { Solano } \\
(5 a-3)\end{array}$ & $\begin{array}{l}\text { 21-19W [Nonpareil x (Nonpareil x } \\
\text { Eureka) A1-30] x 22-20 [Nonpareil } \\
\text { x (Nonpareil x Eureka) A1-30] }\end{array}$ & 0.375 \\
\hline U.S. & Emerald & Mission x (Nonpareil x Mission) & 0.250 \\
\hline U.S. & Profuse & Nonpareil $\mathrm{x}$ Jordanolo & 0.250 \\
\hline U.S. & Wawona & Ruby $x$ Mission & 0.250 \\
\hline U.S. & Kapareil & $\begin{array}{c}\text { Nonpareil x 24-6[Sel. A525 } \\
\text { (Nonpareil x Eureka) x Eureka] }\end{array}$ & 0.125 \\
\hline U.S. & Milow & $\begin{array}{c}\text { Nonpareil x 24-6[Sel. A525 } \\
(\text { Nonpareil x Eureka) x Eureka] }\end{array}$ & 0.125 \\
\hline U.S. & Vesta & $\begin{array}{c}\text { Solano }(5 a-3) \times \text { late blooming } \\
\text { sport of Nonpareil }\end{array}$ & 0.094 \\
\hline U.S. & Davey & Nonpareil x Sans Faute & 0.063 \\
\hline France & Ferralise & Ferraduel $x$ Ferragnes & 0.250 \\
\hline
\end{tabular}

California as 'Princesse', which originated in the Languedoc area of France (Grasselly and Crossa-Raynaud, 1980). 'Languedoc', also known as 'Princes', was also introduced from the Languedoc area of France (Kester et al., 1991).

The Russian cultivars trace back to eight founding clones (Table 3). Three of the founding clones are of Russian origin ('Nikitski 62', 'Nikitski 1', and 'Nikitski 53'), while the other five are from France ('Princesse' and 'Languedoc'), Italy ('Fragullio' and 'Reams'), and the United States ('Nonpareil'). The dominant cultivar used in Russian breeding programs is 'Nikitski 62' (GC = $38.9 \%$ ), followed by 'Princesse' $(\mathrm{GC}=16.7 \%)$. 'Nikitski 1', 'Languedoc', and 'Nonpareil' have a GC of $11.1 \%$.

The French almond-breeding program is characterized by the extensive use of four founding clones: 'Ai' (France) $(\mathrm{GC}=$ $35.7 \%)$, 'Cristomorto' (Italy) (GC = 35.7\%), 'Tuono' (Italy) (GC $=14.3 \%)$, and 'Ardechoise' (France) $(\mathrm{GC}=7.1 \%)$ (Table 3$)$. All other French almond cultivars are of a chance seedling origin with unknown parentage except some speculative parentage relationship between old cultivars such as 'Fourcouronne', 'Tournefort', and 'Tardive de la Verdière' (Grasselly and Crossa-Raynaud, 1980).

The cultivars released from the Spanish breeding program are

Table 3. The percent genetic contribution of founding clones in all cultivars in the respective country of origin.

\begin{tabular}{|c|c|c|}
\hline Founding clone & $\begin{array}{c}\text { Country } \\
\text { of } \\
\text { origin }\end{array}$ & $\begin{array}{c}\text { Genetic contribution } \\
\text { within each country } \\
(\%)\end{array}$ \\
\hline \multicolumn{3}{|c|}{ American } \\
\hline Nonpareil & United States & 37.9 \\
\hline Mission & United States & 30.2 \\
\hline Princesse & France & 21.6 \\
\hline Languedoc & France & 14.1 \\
\hline I.X.L. & United States & 3.9 \\
\hline Eureka & United States & 2.3 \\
\hline Harriott & United States & 1.6 \\
\hline Ne Plus Ultra & United States & 1.3 \\
\hline \multicolumn{3}{|c|}{ Russian } \\
\hline Nikitski 62 & Russia & 38.9 \\
\hline Princesse & France & 16.7 \\
\hline Nikitski 1 & Russia & 11.1 \\
\hline Nonpareil & United States & 11.1 \\
\hline Languedoc & France & 11.1 \\
\hline Nikitski 53 & Russia & 5.6 \\
\hline Fragullio & Italy & 5.6 \\
\hline Reams & Italy & 5.6 \\
\hline \multicolumn{3}{|c|}{ French } \\
\hline Cristomorto & Italy & 41.7 \\
\hline $\mathrm{Ai}$ & France & 33.3 \\
\hline Tuono & Italy & 16.7 \\
\hline Ardechoise & France & 8.3 \\
\hline \multicolumn{3}{|c|}{ Spanish } \\
\hline Tuono & Italy & 50.0 \\
\hline Ferragnes & France & 16.7 \\
\hline Tardive & France & 16.7 \\
\hline \multicolumn{3}{|c|}{ Israeli } \\
\hline Greek & Israel & 25.0 \\
\hline Marcona & Spain & 25.0 \\
\hline Princesse & France & 25.0 \\
\hline
\end{tabular}


Table 4. Coefficients of coancestry for U.S. almond cultivars. ${ }^{\mathrm{Z}}$

\begin{tabular}{|c|c|c|c|c|c|c|c|c|c|c|c|c|c|c|c|c|c|c|}
\hline Cultivars & $1^{y}$ & 2 & 3 & 4 & 5 & 6 & 7 & 8 & 9 & 10 & 11 & 12 & 13 & 14 & 15 & 16 & 17 & 18 \\
\hline 1 Arbuckle $^{\mathrm{w}}$ & $250^{v}$ & 125 & 125 & 016 & 250 & 125 & 125 & 063 & 156 & 125 & $--^{u}$ & 063 & 125 & 156 & 125 & 125 & 250 & 125 \\
\hline 2 Ballico & & & --- & --- & 188 & 125 & 125 & 125 & 125 & --- & --- & --- & --- & --- & --- & 125 & 250 & --- \\
\hline 3 Davey & & & & 047 & 070 & --- & --- & --- & 094 & 140 & --- & 188 & 141 & 176 & 141 & --- & --- & 176 \\
\hline 4 Dehn & & & & & 008 & --- & --- & --- & 063 & 016 & --- & 125 & 016 & 020 & 016 & --- & --- & 020 \\
\hline 5 Emerauld & & & & & & 188 & 188 & 094 & 203 & 063 & --- & 031 & 063 & 078 & 063 & 188 & 375 & 078 \\
\hline 6 Empire & & & & & & & 125 & 063 & 125 & --- & --- & --- & --- & --- & --- & 125 & 250 & --- \\
\hline 7 Fritz & & & & & & & & 063 & 125 & --- & --- & --- & --- & --- & --- & 125 & 250 & --- \\
\hline 8 Golden Stree & & & & & & & & & 063 & --- & --- & --- & --- & --- & --- & 250 & 125 & --- \\
\hline 9 Granada & & & & & & & & & & 031 & --- & 250 & 031 & 039 & 031 & 125 & 250 & 039 \\
\hline 10 Harpareil & & & & & & & & & & & 250 & 063 & 250 & 156 & 125 & --- & --- & 156 \\
\hline 11 Harriott & & & & & & & & & & & & --- & 250 & --- & --- & --- & --- & --- \\
\hline 12 I.X.L & & & & & & & & & & & & & 063 & 078 & 063 & --- & --- & 078 \\
\hline 13 Jordanolo & & & & & & & & & & & & & & 156 & 125 & --- & --- & 156 \\
\hline 14 Kapareil & & & & & & & & & & & & & & & 156 & --- & --- & 344 \\
\hline 15 Kutsch & & & & & & & & & & & & & & & & --- & --- & 156 \\
\hline 16 Languedoc & & & & & & & & & & & & & & & & & 250 & --- \\
\hline 17 Mission & & & & & & & & & & & & & & & & & & --- \\
\hline \multicolumn{19}{|l|}{18 Milow } \\
\hline \multicolumn{19}{|l|}{19 Moneytree } \\
\hline \multicolumn{19}{|l|}{20 Monarch } \\
\hline \multicolumn{19}{|l|}{21 Nonpareil $^{\mathrm{s}}$} \\
\hline \multicolumn{19}{|c|}{22 Ne Plus Ultra } \\
\hline \multicolumn{19}{|l|}{23 Northland } \\
\hline \multicolumn{19}{|l|}{24 Padre } \\
\hline \multicolumn{19}{|l|}{25 Reinero } \\
\hline \multicolumn{19}{|l|}{26 Profuse } \\
\hline \multicolumn{19}{|l|}{27 Sans Faute } \\
\hline \multicolumn{19}{|c|}{28 Sydney Special } \\
\hline \multicolumn{19}{|l|}{29 Sonora } \\
\hline \multicolumn{19}{|l|}{30 Solano } \\
\hline \multicolumn{19}{|l|}{31 Spencer } \\
\hline \multicolumn{19}{|l|}{32 Utah } \\
\hline \multicolumn{19}{|l|}{33 Vesta } \\
\hline \multicolumn{19}{|l|}{34 Wawona } \\
\hline \multicolumn{19}{|l|}{35 Swanson } \\
\hline \multicolumn{19}{|l|}{36 Ureka } \\
\hline 37 Princesse (I & & & & & & & & & & & & & & & & & & \\
\hline
\end{tabular}

${ }^{\mathrm{z} C u l t i v a r s}$ with mean $\mathrm{CC}=0$ were not included.

${ }^{y}$ Numbers across top of table refer to cultivar numbers at far left of table.

${ }^{\mathrm{x}}$ Mean coefficients of coancestry calculated with dashes $=0$.

${ }^{w}$ Represents all 'Nonpareil' $x$ 'Mission' offspring.

${ }^{\mathrm{v}} \mathrm{CC}$ values are $\times 10^{3}$.

"Dashes indicate no inbreeding of known parents.

${ }^{t}(F)=$ cultivar originated from France.

'Mutations of 'Nonpareil', considered as 'Nonpariel', were not included in the table.

from three founding clones: 'Tuono' from Italy $(\mathrm{GC}=50 \%)$, 'Ferragnes', and 'Tardive de la Verdière' from France $(\mathrm{GC}=$ $16.7 \%$ ) (Table 3).

In Israel, the six cultivars grown are of Israeli origin. Four of them have been obtained through breeding programs involving three founding clones from three countries ('Greek' from Israel, 'Marcona' from Spain, and 'Princesse' originally from France but probably imported from the United States). The GC of each of these cultivars is $25 \%$ (Table 3 ).

Coefficients of coancestries. Even though several almond cultivars have inbreeding coefficients greater than zero, cultivars released from breeding programs show important coancestry relationships through the repeated use of a few superior parents.

U.S. germplasm. Coefficients of coancestries (CC) of cultivars in the U.S. germplasm range between 0 and 0.5 (Table 4). The average $\mathrm{CC}$ values for individual cultivars paired with all other cultivars range between 0 and 0.15 with an overall mean of 0.080 for the 85 cultivars. Except for 12 cultivars of unknown origin and 'Nonpareil' and 'Mission', which are unrelated, all of the remaining 71 cultivars $(84 \%)$ are interrelated. Seven percentof the cultivars represent a parent-offspring relationship $(\mathrm{CC}=0.25)$, while $2 \%$ are full sibs. Fourteen percent represent a half-sib relationship $(\mathrm{CC}=0.125)$ and $4 \%$ have $\mathrm{CC}=0.063$ (first-cousin relationship). On the average, every cultivar is related to 38 other cultivars with a range between 1 ('Swanson' founding clone) and 69 (all 'Nonpareil' $\mathrm{x}$ 'Mission' hybrids).

Russian germplasm. The twelve Russian cultivars and five foreign cultivars ('Princesse', 'Reams', 'Fragillio', 'Languedoc', 


\begin{tabular}{|c|c|c|c|c|c|c|c|c|c|c|c|c|c|c|c|c|c|c|c|}
\hline 19 & 20 & 21 & 22 & 23 & 24 & 25 & 26 & 27 & 28 & 29 & 30 & 31 & 32 & 33 & 34 & 35 & 36 & 37 & $\operatorname{Mean}^{\mathrm{x}}$ \\
\hline 125 & 125 & 250 & 063 & 031 & 125 & 125 & 188 & 031 & 031 & 188 & 188 & 125 & 031 & 125 & 203 & --- & --- & 125 & 147 \\
\hline --- & 125 & --- & --- & --- & 125 & --- & --- & --- & --- & --- & --- & --- & --- & --- & 188 & --- & --- & --- & 069 \\
\hline 140 & --- & 281 & 094 & 094 & --- & 141 & 211 & 281 & 094 & 211 & 211 & 140 & 094 & 153 & 023 & --- & --- & 188 & 063 \\
\hline 016 & --- & 031 & 031 & 250 & --- & 016 & 023 & 063 & 063 & 023 & 023 & 016 & 063 & 025 & 008 & --- & --- & 063 & 012 \\
\hline 063 & 188 & 125 & 031 & 016 & 188 & 063 & 094 & 016 & 016 & 094 & 094 & 063 & 016 & 063 & 289 & --- & --- & 063 & 136 \\
\hline --- & 125 & --- & --- & --- & 125 & --- & --- & --- & --- & --- & --- & --- & --- & --- & 188 & --- & --- & --- & 065 \\
\hline --- & 125 & --- & --- & --- & 125 & --- & --- & --- & --- & --- & --- & --- & --- & --- & 188 & --- & --- & --- & 068 \\
\hline --- & 063 & --- & --- & --- & 063 & --- & --- & --- & --- & --- & --- & --- & --- & --- & 094 & --- & --- & --- & 037 \\
\hline 031 & 125 & 063 & 063 & 125 & 125 & 031 & 047 & 125 & 125 & 047 & 047 & 031 & 125 & 065 & 203 & --- & --- & 125 & 096 \\
\hline 125 & --- & 250 & 063 & 031 & --- & 125 & 250 & 031 & 031 & 188 & 188 & 125 & 031 & 125 & 016 & --- & --- & 125 & 062 \\
\hline --- & --- & --- & --- & --- & --- & --- & 125 & --- & --- & --- & --- & --- & --- & --- & --- & --- & --- & --- & 008 \\
\hline 063 & --- & 125 & 125 & 250 & --- & 063 & 094 & 250 & 250 & 094 & 094 & 063 & 250 & 109 & 031 & --- & --- & 250 & 060 \\
\hline 125 & --- & 250 & 063 & 031 & --- & 125 & 375 & 031 & 031 & 188 & 188 & 125 & 031 & 125 & 016 & --- & --- & 125 & 064 \\
\hline 156 & --- & 313 & 078 & 039 & --- & 156 & 234 & 039 & 039 & 281 & 281 & 156 & 039 & 180 & 020 & --- & 188 & 156 & 104 \\
\hline 125 & --- & 250 & 063 & 031 & --- & 125 & 188 & 031 & 031 & 188 & 188 & 125 & 031 & 125 & 016 & --- & --- & 125 & 078 \\
\hline --- & 125 & --- & --- & --- & 125 & --- & --- & --- & --- & --- & --- & --- & --- & --- & 188 & --- & --- & --- & 068 \\
\hline --- & 250 & --- & --- & --- & 250 & --- & --- & --- & --- & --- & --- & --- & --- & --- & 375 & --- & --- & --- & 129 \\
\hline \multirow[t]{19}{*}{156} & --- & 313 & 078 & 039 & --- & 156 & 234 & 039 & 039 & 281 & 281 & 156 & 039 & 148 & 020 & --- & 188 & 156 & 104 \\
\hline & --- & 250 & 063 & 031 & --- & 125 & 188 & 031 & 031 & 188 & 188 & 125 & 031 & 125 & 016 & --- & --- & 125 & 078 \\
\hline & & --- & --- & --- & 125 & --- & --- & --- & --- & --- & --- & --- & --- & --- & 188 & --- & --- & --- & 065 \\
\hline & & & 125 & 063 & --- & 250 & 375 & 063 & 063 & 375 & 375 & 250 & 063 & 250 & 031 & --- & --- & 250 & 152 \\
\hline & & & & 063 & --- & 063 & 094 & 063 & 063 & 094 & 094 & 063 & 063 & 109 & 031 & --- & --- & 250 & 060 \\
\hline & & & & & --- & 031 & 047 & 125 & 125 & 047 & 047 & 031 & 125 & 055 & 016 & --- & --- & 125 & 033 \\
\hline & & & & & & --- & --- & --- & --- & --- & --- & --- & --- & --- & 188 & 250 & --- & --- & 068 \\
\hline & & & & & & & 188 & 031 & 031 & 188 & 188 & 125 & 031 & 125 & 016 & --- & --- & 125 & 077 \\
\hline & & & & & & & & 047 & 047 & 281 & 281 & 188 & 047 & 188 & 023 & --- & --- & 188 & 120 \\
\hline & & & & & & & & & 125 & 047 & 047 & 031 & 125 & 055 & 016 & --- & --- & 125 & 033 \\
\hline & & & & & & & & & & 047 & 047 & 031 & 125 & 055 & 016 & --- & --- & 125 & 031 \\
\hline & & & & & & & & & & & 500 & 188 & 047 & 297 & 023 & --- & 125 & 188 & 122 \\
\hline & & & & & & & & & & & & 188 & 047 & 422 & 023 & --- & 125 & 188 & 122 \\
\hline & & & & & & & & & & & & & 031 & 125 & 016 & --- & --- & 125 & 078 \\
\hline & & & & & & & & & & & & & & 055 & 016 & --- & --- & 125 & 031 \\
\hline & & & & & & & & & & & & & & & 027 & --- & 063 & 219 & 072 \\
\hline & & & & & & & & & & & & & & & & --- & --- & 063 & 109 \\
\hline & & & & & & & & & & & & & & & & & --- & --- & 003 \\
\hline & & & & & & & & & & & & & & & & & & --- & $\begin{array}{l}008 \\
106\end{array}$ \\
\hline
\end{tabular}

and 'Nonpareil') used in the Russian breeding programs have CC values between 0 and 0.250 . The average $C C$ value over all the cultivars tested is 0.061 . Coefficients of coancestries mean values for cultivars showing coancestry relationships and taken individually vary between 0.015 for 'Nikitski 53 ', 'Reams', and 'Fragillio', and 0.103 for 'Nikitski 62 '. Ten percent of the cultivars from the Russian breeding programs have a parent-offspring relationship $(C C=0.250)$ and $4 \%$ are full-sibs $(C C=0.250)$. Fifteen percent of these cultivars represent a half-sib relationship $(\mathrm{CC}=0.125)$, and $5 \%$ are of first-cousin type coancestry $(\mathrm{CC}=0.063)$. Every released cultivar from a controlled cross is related to at least seven other cultivars.

French germplasm. The mean CC among the cultivars released from French breeding programs and two foreign cultivars used as parents ('Cristomorto' and 'Tuono') is 0.121. 'Ferralise' represents the highest coancestry value $(\mathrm{CC}=0.375)$ with its parents 'Ferragnes' and 'Ferraduel'. Every cultivar is related to at least six other cultivars. Eight percent of the cultivars have a full-sib relationship and $20 \%$ have a parent-offspring relationship (CC $=$ $0.250)$. Nineteen percent are half-sibs $(\mathrm{CC}=0.125)$, and $1 \%$ are first cousins $(\mathrm{CC}=0.063)$.

Spanish germplasm. The overall mean CC among the three Spanish cultivars released from breeding programs ('Moncaya', 'Ayles', and 'A-10-6') and the three foreign cultivars used as parents in the breeding programs ('Tardive de la Verdière', 'Tuono', and 'Ferragnes') was 0.108. Three cultivars, 'A-10-6', 'Ayles', and 'Moncayo', are half-sibs $(\mathrm{CC}=0.125)$. The other $\mathrm{CCs}$ that differ from zero are parent-offspring relationships $(C C=0.250)$. 
Table 5. Mean of coancestry coefficients among almond cultivars from five almond-producing countries.

\begin{tabular}{lccccc}
\hline \hline Country & $1^{\mathrm{z}}$ & 2 & 3 & 4 & 5 \\
\hline 1) U.S. & 0.080 & 0.030 & $---\mathrm{y}$ & --- & 0.035 \\
2) Russia & & 0.061 & --- & --- & 0.013 \\
3) France & & & 0.121 & 0.067 & --- \\
4) Spain & & & & 0.108 & --- \\
5) Israel & & & & & 0.093
\end{tabular}

${ }^{\mathrm{z} N u m b e r s ~ a c r o s s ~ t o p ~ o f ~ t a b l e ~ r e f e r ~ t o ~ c o u n t r y ~ n u m b e r s ~ a t ~ f a r ~ l e f t ~ o f ~ t a b l e . ~}$ y Dashes indicate no inbreeding of the known parents.

Every released cultivar is related to at least three other cultivars. Israeli germplasm. The six Israeli cultivars and the three foreign cultivars ('Marcona', 'Nonpareil', and 'Princess') used in the Israeli breeding programs have an overall mean CC of 0.093 . Coefficients of coancestries values vary between 0 and 0.250 . All CCs equalling 0.250 (31\% of the cultivars studied) represent a parent-offspring relationship, with the exception of a full-sib relationship between 'Solo' and 'Samish'. Fourteen percent of the coancestry relationships are of the half-sib type $(C C=0.125)$. Every released cultivar is related to five or six other cultivars. Some of the original parents are introduced cultivars. 'Princesse' is a French cultivar, probably introduced from the United States, 'Nonpareil' is from the United States, and 'Marcona' is from Spain.

Coancestry relationships among cultivars from different countries. Germplasm exchange between almond breeders in different countries has resulted in common use of some cultivars as parents. When mean CCs across cultivars within countries are considered, U.S., Russian, and Israeli almond cultivars share common parentage (Table 5). The mean CC between U.S. and Russian almond cultivars is 0.030 , which is less than the $\mathrm{CC}$ mean values in U.S. and Russian cultivars ( 0.080 and 0.061 , respectively). This parental relationship is mainly explained by the use of 'Princesse' and 'Languedoc,' old French cultivars, in breeding programs of both countries, and from the use of 'Nonpareil' from the U.S. by Russian breeders. The mean CC between U.S. and Israel cultivars is 0.035 . The French cultivar 'Princesse' and the U.S. cultivar 'Nonpareil' are found in pedigrees of cultivars from both countries. 'Princesse' and 'Nonpareil' are also the two common cultivars used by Russian and Israeli breeders, resulting in a CC of 0.013 between the two countries. In addition, there is a coancestry relationship among cultivars between Spain and France. This coancestry relationship $(\mathrm{CC}=0.067)$ resulted from the common use of the Italian cultivar 'Tuono' in both breeding programs and by the use of 'Ferragnes', a French release, in Spanish breeding programs.

\section{Discussion}

The repeated use of a few founding clones and their progeny as parents in almond-breeding programs may eventually result in loss of genetic variability and a concomitant increase in inbreeding depression in future generations. This potential genetic limitation is of particular concern since new cultivars may eventually replace local seedling ecotypes. Similar situations have been reported for numerous species (Hancock and Siefker, 1982; Lyrene, 1983; Mendoza and Haynes, 1974; Reynders and Monet, 1987; Scorza et al., 1985; Sjulin and Dale, 1987).

Most cultivars presently grown are hybrids of a few unrelated parents (e.g., 'Nonpareil' and 'Mission' in the United States). The mean inbreeding coefficient for U.S. almond cultivars is lower than that of plums (Byrne, 1989), and 4.5 to 8 times lower than that of peaches (Reynders and Monet, 1987; Scorza et al., 1985). The analyses presented herein suggest that limited inbreeding has occurred in U.S. almond germplasm to date. However, the high degree of coancestry may limit future progress and introduce undesirable traits (e.g., noninfectious bud failure). The outstanding kernel characteristics and industry importance of 'Nonpareil' led to its extensive use as a parent in breeding programs. Most often it was crossed with the late-blooming cultivar Mission (Kester et al., 1991). Aside from the extensive breeding use of Nonpareil and Mission, these two cultivars represent, respectively, $65 \%$ and $25 \%$ of commercial almond production in California (Hauagge et al., 1987). This uniformity increases the vulnerability of California almond production to yield fluctuations due to hazards such as the bud failure disorder that is frequent with 'Nonpareil' and its descendants, which represent $48 \%$ of the cultivars examined (Kester, 1970).

Almond cultivars in other countries, except the French cultivar 'Ferralise', are not inbred. They are mostly selections of chance seedlings, with a limited number of cultivars from controlled crosses. The highest number of cultivars showing inbreeding are from breeding programs that have had more cycles of selection.

The major objectives in Russian breeding programs are frost and cold resistance combined with nut quality. 'Nikitski 62', known for its late bloom and cold hardiness, is a frequent parent (Denisov, 1988; Rikhter, 1964, 1969).

In Western Europe and North Africa, the main objectives in breeding almonds are similar, i.e., late bloom and self-compatibility (Grasselly, 1984). As a result, a few common cultivars are being used extensively as parents, such as 'Tuono', 'Ferragnes', 'Ai', and 'Cristomorto'.

Almond-breeding programs in different countries are characterized by the use of a few superior genotypes as parents. Selection of outstanding individuals as new cultivars or as parents has provided substantial improvement in important commercial traits. However, the diverse almond germplasm used in several European countries is already being replaced by a few superior cultivars (Grasselly, 1984). This situation is fostered by germplasm exchange, and in the near future will probably increase coancestry relationships between released almond cultivars, and might, in the future, affect genetic gain, narrow the almond genetic base, and increase the hazard of epidemics.

\section{Literature Cited}

Anonymous. 1977. Etudes de quelques aspects morphologiques et physiologiques pour l'identification de 16 variétés d'amandier Espagnol. 3rd colloq. G.R.E.M.P.A.

Asai, W., W.C. Micke, D. Rough, L. Hendricks, and D.E. Kester. 1994. Selection of varieties. In: W. Micke (ed.). Almond Orchard Manual. Univ. of Calif. Berkeley Div. Agr. Sci. Publ., Berkeley.

Barbera, G., G. Fatta Del Bosco, and G. Occorso. 1984. Caractères pomologiques de 94 variétés d'amandier de la Sicile occidentale. Options Meditérranéennes 84:3-12.

Bastide, J. and B. Souty. 1976. L'Amandier en France. Options Mediterranéennes 32:80-82.

Brooks, R.M. and H.P. Olmo. 1972. Register of new fruit and nut varieties. 2nd ed. Univ. of California Press. p. 1-7.

Brooks, R.M. and H.P. Olmo. 1982. Register of new fruit and nut varieties list 32. HortScience 17:17-21.

Byrne, D.H. 1989. Inbreeding, coancestry, and founding clones of Japanese-type plums of California and the Southeastern United States. J. Amer. Soc. Hort. Sci. 114:699-705.

Chessa, I. and M. Pala. 1985. Survey of the patrimony of almond varieties in Sardinia. Options Mediterranéennes 85:97-103. 
Costetchi, M. 1967. Soiuri de migdal cultivate in Romania, p. 503-621. Pomologia Republicii Socialiste Romania. vol. 6. Academiei Republicii Socialiste Romania. Bucaresti.

Crossa-Raynaud, P. and C. Grasselly. 1985. Existance de groupes d'interstérilité chez l'Amandier. Options Meditérranéennes 85:43-45.

Denisov, V.P. 1988. Almond genetic resources in the U.S.S.R. and their use in production and breeding. Acta Hort. 224:299-306.

Egea, L., J.E. Garcia, J. Egea, and T. Berenguer. 1984. Premières observations sur une collection de 81 variétés d'Amandiers situés au Sud-Est Espagnol. Options Meditérranéennes 84:13-26.

Evreinoff, V.A. 1958. Contribution à l'étude de l'amandier. Fruits et Primeurs de l'Afrique 28:99-104.

Fanelli, L. 1939. Varietà pugliesi di mandorle.(In Italian.) Commissione per lo Studio del Miglioramento della Coltura del Mandorlo. FaviaBari-Roma. 1939-xvii:118-229.

Felipe, A.J. 1976. La production d'amandes en Espagne. Options Mediterranéennes 32:83-91.

Felipe, A. 1984. Collection de variétés d'amandier du CRIDA-03(INIA)Saragosse. Options Meditérranéennes 84:51-52.

Felipe, A. J. and R. Socias i Company. 1985. L'Amélioration de L'amandier à Saragosse. Options Meditérranéennes 85:31-38.

Felipe, A. and R. Socias i Company. 1987. 'Ayles', 'Guara', and 'Moncayo' almonds. HortScience 22:961-962.

Georgio, V., A. Reina, and F. Guida. 1985. 'Tribuzio Tardiva': Un semis d'amandier à floraison très tardive. Options Meditérranéennes 85:1923.

Godini, A., E. Ferrara, A. Reina, V. Giorgia, and F. Guida. 1977. Contributo alla conoscenza delle cultivar di mandorlo (P.amygdalus Batsch) della Puglia, p. 194-206. 3rd colloq. G.R.E.M.P.A. CIHEAM. Bari, Italy.

Grasselly, Ch. 1976. Origine et évolution de l'amandier cultivé. Options Meditérranéennes 32:45-48.

Grasselly, Ch. 1984. Réflexions diverses sur l'évolution des objectifs d'amélioration de l'amandier. Options Meditérranéennes 84.

Grasselly, Ch. and G. Olivier. 1976. Mise en évidence de quelques types autocompatibles parmi les cultivars d'amandier (Prunus amygdalus) de la population des Pouilles. Ann. Amelior. Plantes 26:107-113.

Grasselly, Ch. and G. Olivier. 1981. Difficulté de survie de jeunes semis d'amandier dans certaines descendances. Options Méditerranéenes 81:65-67.

Grasselly, Ch. and P. Crossa-Raynaud. 1980. In: G.P. Maisonnueve \& Larose (eds.). L'Amandier.

Grasselly, Ch., P. Crossa Raynaud, G. Olivier, and H. Gall. 1981. Transmission du caractère d'auto-compatibilité chez l'amandier (Amygdalus communis). Options Meditérranéennes 81:71-75.

Hancock, J.F. and J.H. Siefker. 1982. Levels of inbreeding in highbush blueberry cultivars. HortScience 17:363-366.

Hauagge, R., D.E. Kester, S. Arulsekar, D.E. Parfitt, and L. Liu. 1987. Isozyme variation among California almond cultivars: II. Cultivar characterization and origins. J. Amer. Hort. Sci. 112:693-698.

Jaouani, A. 1976. La culture de l'amandier en Tunisie. Options Meditéranéennes 32:67-71.

Kester, D.E. 1970. Noninfectious bud failure from breeding programs of almond (Prunus amygdalus Batsch). J. Amer. Soc. Hort. Sci. 95:492496.

Kester, D.E. 1990. The biological and cultural evolution of the almond. 1st
Congr. Iber. de Cien. Actas. Hort. 4:54-63.

Kester, D.E. and R. Asay. 1975. Almonds, p. 387-419. In: J. Janick and J.N. Moore (eds.). Advances in fruit breeding. Purdue Univ. Press, West Lafayette, Ind.

Kester, D.E., R.N. Asay, and W.C. Micke. 1984. 'Solano', 'Sonora', and 'Padre' almonds. HortScience 19:138-139.

Kester, D.E., T.M. Gradziel, and Ch. Grasselly. 1991. Almonds (Prunus). p. 701-758. In: J.N. Moore and J.R. Ballington, Jr. (eds.). Genetic Resources of temperate fruit and nut crops. Acta Hort. No. 290, ISHS Wageningen.

Lyrene, P. 1983. Inbreeding depression in rabbiteye blueberries. HortScience 18:226-227.

Mendoza, H.A. and F.L. Haynes. 1974. Genetic relationships among potato cultivars grown in the United States. HortScience 9:328-330.

Monastra, F., G. Della Strada, C. Fideghelli, and R. Quarta. 1984. Etude pomologique de soixante-dix variétés d'origine differente. Options Mediterranéennes 84:27-37.

Reynders, S. and R. Monet. 1987. Evolution au cours du temps, de la consanguinité des variétés de pecher. Etudes des distances génétiques entre quelques géniteurs. Fruits 42:529-535.

Rikhter, A.A. 1964. Results of practical and theoretical work of almond breeding and cultivar study. (In Russian.) Tr. Gos. Nikit. Bot. Sad. 37:91-107.

Rikhter, A.A. 1969. Ways and methods of almond breeding. (In Russian.) Tr. Gos. Nikit. Bot. Sad. 43:81-94.

Serafimov, S. 1976. L'Amandier en Bulgarie. Options Meditérranéennes 32:60-65.

Scorza, R., S.A. Mehlenbacher, and G.W. Lightner. 1985. Inbreeding and coancestry of freestone peach cultivars of the Eastern United States and implications for peach germplasm improvement. J. Amer. Soc. Hort. Sci. 110:547-552.

Sjulin, T.M. and A. Dale. 1987. Genetic diversity of North American strawberry cultivars. J. Amer. Soc. Hort. Sci. 112:375-385.

Socias i Company, R. 1990. Breeding self-compatible almonds. Plant Breeding Rev. 8:313-337.

Spiegel-Roy, P. 1976. L'Amandier en Israel. Options Meditérranéennes 32:92-95.

Spiegel-Roy, P. and J. Kochba. 1976a. 'Dagan' almond. HortScience 11:271.

Spiegel-Roy, P. and J. Kochba. 1976b. 'Solo' almond. HortScience 11:271-272.

Spiegel-Roy, P., J. Kochba, and R. Iris. 1982. ‘Samish’ almond. HortScience 17:271.

Stylianides, D. 1976. La culture de l'amandier en Grece. Options Meditérranéennes 32:72-73.

Stylianides, D. 1977. New almond varieties created by breeding in Greece, p. 140-149. 3rd Colloq. G.R.E.M.P.A. CIHEAM. Bari, Italy.

Vargas Garcia, F.J. 1975. El almendro en la provincia de Tarragona, p. 58131. EXCMA. Diputación Provincial de Tarragona. Fundación Servicio Agropecuario Provincial.

Vlasic, A. 1976. La cultivazione del mandorlo in Jugoslavia. Options Meditérranéennes 32:75-77.

Wood, M.N. 1924. Almond varieties in the United States. U.S. Dept. of Agr. Bul. No. 1282.

Wright, S. 1922. Coefficients of inbreeding and relationship. Amer. Natl. 56:330-338. 